\title{
Joalheria de Crioulas: Subversão e Poder no Brasil Colonial
}

\author{
Crioula Jewelery: Subversion and Power in Colonial Brazil
}

\author{
Amanda Gatinho Teixeira ${ }^{1}$
}

\section{RESUMO}

O uso de joias sempre esteve presente ao longo do tempo nas mais diversas civilizações. Contendo significados para além da ornamentação, as joias podem ser analisadas como objetos que materializam posições sociais, poder espiritual, alegria, amor, luto, proteção, entre outras características. Durante o Período Colonial Brasileiro, foram produzidas e utilizadas as emblemáticas Joias de Crioulas Afro-Brasileiras, as quais são consideradas os primeiros exemplares da joalheria eminentemente nacional. Estas joias também representavam a ascensão econômica e a subversão às leis suntuárias que proibiam o uso destes adornos pelas escravizadas, além de exibirem veladamente devoções religiosas e colocarem em prática códigos de comportamento, de hierarquia social e de poder entre o grupo das alforriadas e libertas deste período. Para isso, recorro à historiografia do Brasil Colonial, à história do design de joias e aos estudos antropológicos concernentes à cultura material.

Palavras-chave: Joias de Crioulas Afro-Brasileiras. Joalheria. Período Colonial Brasileiro. Cultura Material. Hibridação..

\section{ABSTRACT}

The use of jewels has always been present over time in the most diverse civilizations. Containing meanings beyond ornamentation, jewels can be analyzed as objects that materialize social positions, spiritual power, joy, love, mourning, protection, among other characteristics. During the Brazilian Colonial Period, the emblematic "jewels of Afro-Brazilian Creole" were produced and used, which are considered the first copies of the eminently national jewelry. These jewels also represented the economic ascent and subversion to the sumptuary laws that prohibited the use of these adornments by the slaves, as well as veiled religious devotions and put into practice codes of behavior, social hierarchy and power among the freed and liberates from this period. For this, I turn to the historiography of Colonial Brazil, the history of jewelry design and anthropological studies concerning material culture.

Keyword: Jewels of Afro-Brazilian Creole. Jewelry. Brazilian Colonial Period. Material Culture. Hybridization.

1 Graduada em Artes (UFPA), Especialista em Design (IESAM) e Mestra em Antropologia (UFPA). E-mail: agteixeira10@gmail.com. 


\section{Introdução}

O ser humano, desde que se distinguiu dos outros animais, buscou com o que se destacar. O desejo pelo embelezamento do corpo foi - e ainda é - característica intrínseca da nossa espécie, o que nos fez criar um simbolismo próprio através de objetos materiais que denotavam poder espiritual, alegria, amor, luto, dentre outros sentimentos. Entre uma das formas de embelezamento que o indivíduo criou, estão as joias, que eram produzidas a partir dos recursos que a natureza oferecia. Assim, no período mais remoto da antiguidade, nossos antepassados usavam o singular, como: conchas com formas peculiares, plumas de pássaros, sementes, pedras polidas, ossos e presas de animais, muitas vezes associados para compor os adornos.

Estes adornos são considerados verdadeiros joias, não pelo seu valor intrínseco, mas, pela importância arqueológica. Só a partir do início da idade do Bronze que surgiram as joias como conhecemos atualmente, com a utilização de metais nobres como o ouro e a prata combinados com pedras de cor (GOLA, 2008, p.31).

Assim, em todas as civilizações, o ser humano sempre utilizou alguma forma de adereço, e a necessidade de ataviar-se parece arraigada ao longo de sua história, o que tornou os ornamentos corporais como legítimos objetos historiográficos que, quando dispensados uma maior atenção a eles, ajuda-nos a compreender melhor o passado e o presente (PAIVA, 2006, p.218).

Dessa forma, este artigo privilegiará o recorte histórico do Brasil Colonial, por ser o período em que foram produzidas as chamadas Joias de Crioulas Afro-Brasileiras ${ }^{2}$, consideradas os primeiros exemplares da joalheria nacional (FACTUM, 2009, p.29), analisando-as como objetos que materializam posições, identidades e status entre o grupo das escravizadas, alforriadas e libertas. Assim, o presente artigo é baseado na historiografia do Brasil Colonial, apontando a resistência e a subversão destas mulheres ao regime, ao criarem e portarem tais objetos; na história do design de joias, contribuindo com a definição da nomenclatura técnica e na observação mais refinada destas joias; e, ainda, nos estudos antropológicos concernentes à cultura material privilegiando o objeto-joia como a materialidade da reconstrução identitária destas.

\footnotetext{
${ }^{2}$ O termo "jóias de crioulas afro-brasileiras" concerne a peças confeccionadas nos séculos XVIII e XIX, o termo consiste em uma coleção de peças compostos por: colares, braceletes, pulseiras, brincos, anéis, penca de balangandãs entre outros objetos de adorno corporal direcionados exclusivamente para as mulheres africanas, mulatas ou crioulas no Brasil, sob a condição de escravizadas, alforriadas ou libertas. Este conceito está embasado de acordo com os estudos do antropólogo Raul Lody (2001), além de respeitar a antiga grafia. Também é válido ressaltar que grande parte do acervo dessas joias encontra-se na coleção do Museu Carlos Costa Pinto, em Salvador-Bahia.
} 


\section{A Cultura Objetificada das Joias de Crioulas}

O ser humano, enquanto ser social, faz uso de diversos veículos de comunicação para a expressão de suas ideias. Nesse sentido, é possível atribuir aos objetos materiais diversas funções, como um meio de expressar simbolicamente nossas identidades individuais e coletivas.

[...] os objetos materiais [possuem] o poder não só de tornar visíveis e estabilizar determinadas categorias socio-culturais, demarcando fronteiras entre estas, como também o poder, não menos importante, de constituir sensivelmente formas específicas de subjetividade individual e coletiva (GONÇALVES, 2007, p.8).

Dentro do extenso orbe de objetos produzidos pela humanidade, ao longo da história, destacamos, por exemplo, as joias, como aquelas as quais recebem inúmeros significados, tais como: símbolos culturais, objetos de ostentação e de distinção entre as pessoas, além de possuir significativo valor artístico, entre outros sentidos culturais.

A joia, como adorno, possui um vínculo com os desejos e intenções do seu usuário de construir novas linguagens através de símbolos e, com eles, significados eficientes na construção de identidades, ou ainda um elemento de inserção social a um determinado grupo.

[...] os objetos materiais são pensados como um sistema de comunicação, meios simbólicos através dos quais indivíduos, grupos e categorias sociais emitem (e recebem) informações sobre seu status e sua posição na sociedade. (GONÇALVES, 2007, p.20).

A necessidade de se adornar parece arraigada profundamente no ser humano e, em muitos momentos, a referida ornamentação compôs um valioso instrumento para reconstrução da nossa história. Como observa Silva,

Enquanto objetos da cultura material pré-histórica, a produção de joias africanas data de tempos remotos - a considerar os achados 
arqueológicos da caverna de Blombos na África do Sul que, dentre outros artefatos líticos encontrados, foram recuperadas contas para colares datadas de 75 mil anos (SILVA, 2011, p.1).

Durante o Período Colonial Brasileiro, por exemplo, as mulheres que aqui chegaram pelo tráfico negreiro, mesmo diante de privações de toda ordem, conseguiram materializar e fazer circular símbolos que expressavam resistência ao regime a que eram submetidas ao trazerem consigo suas culturas e seus saberes, que foram gradualmente mesclados e absorvidos, possibilitando a criação de peças icônicas de joalheria, as chamadas Joias de Crioulas ${ }^{3}$ AfroBrasileiras (Fig. 1).

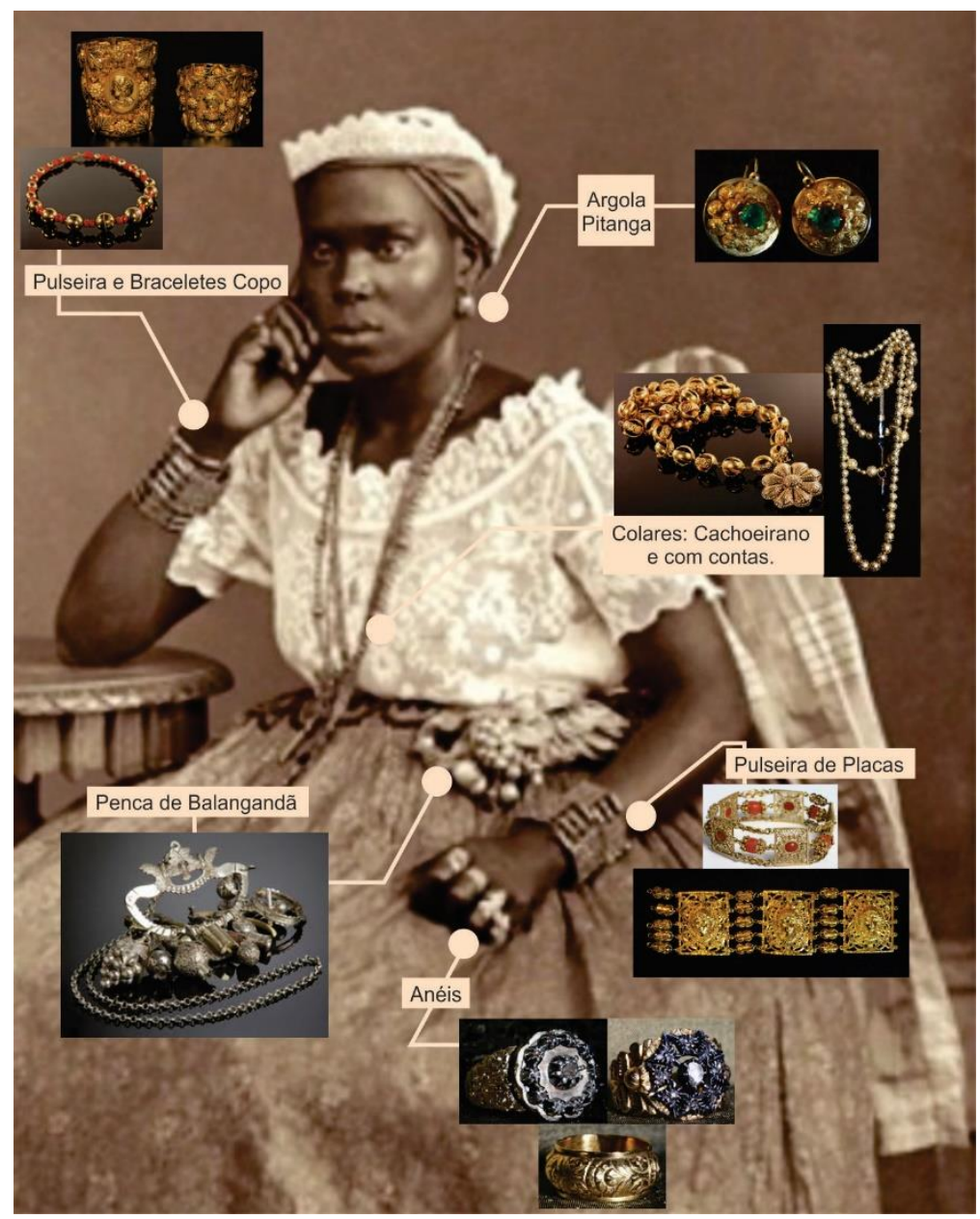

Figura 1: Fotocomposição de uma usuária e suas respectivas joias. Fonte: AUTORA, 2014.

\footnotetext{
3 "A população da cidade dividia-se, segundo sua origem, em brasileiros, africanos e europeus. [...] Mas havia também diferentes cores entre os nascidos no Brasil: o negro que se chamava crioulo; o cabra, mestiço de mulato com crioulo; o mulato, também chamado pardo; e o branco" (REIS, 2003, p.23). Logo, crioulas são as mulheres negras nascidas no Brasil.
} 
Seu uso é observado em diversas obras pictóricas do período, por artistas documentalistas como Carlos Julião e Jean Baptiste Debret (Fig.2) que resgataram das ruas, mercados, festas populares e manifestações religiosas, uma ampla iconografia dos costumes sobre o Brasil africano dos séculos XVIII e XIX.

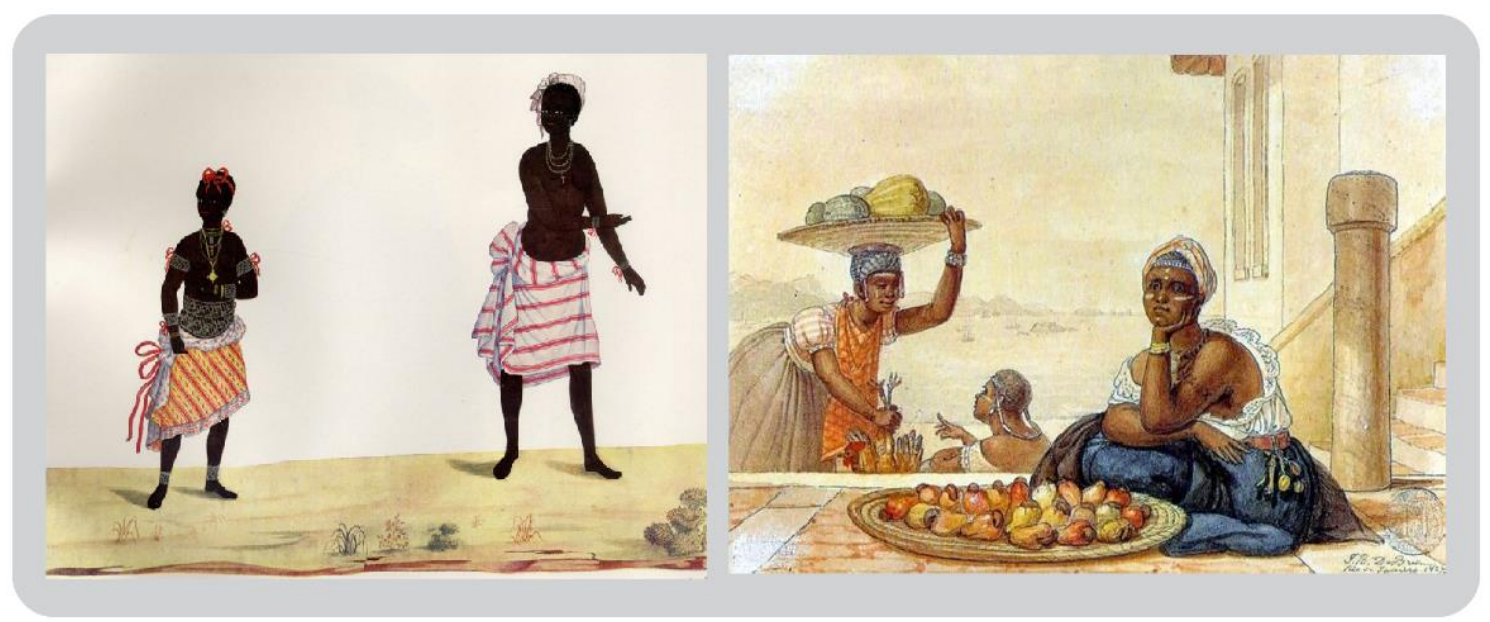

Figura 2: "Riscos iluminados de figurinos de broncos e negros dos Uzos do Rio de Janeiro e Serro Frio" chapa 26 - Aquarela - Carlos Julião.

"Negra tatuada vendendo caju" - Aquarela - Jean Baptiste Debret. Fonte: CUNHA; MILZ, p.2011, p.158 e p.160.

Sabemos que o Brasil Colonial possuía uma característica basilar em sua sociedade, haja vista que esta foi marcada pela pluralidade e pela mobilidade física e cultural dos vários grupos sociais compostos por: brancos, negros, indígenas e mestiços, que se influenciavam continuamente. Segundo Paiva (2006, p.219), o hibridismo cultural atingiu todos os grupos sociais, embora a impermeabilidade de certos costumes também se fizesse presente, ainda que camuflada.

Nesse sentido, algumas tradições foram reforçadas, mas também recriadas e adaptadas, por meio dos contatos cotidianos entre estes grupos, suas origens e seus posicionamentos sociais. Dessa forma, a indumentária deve ser vista como importante elemento simbólico para compreendermos parte da dinâmica social a qual estavam inseridas.

Na medida em que os objetos materiais circulam permanentemente na vida social, importa acompanhar descritiva e analiticamente seus deslocamentos e suas transformações (ou reclassificações) através dos diversos contextos sociais e simbólicos [...]. Acompanhar o deslocamento dos objetos ao longo das fronteiras que delimitam esses contextos é em grande parte entender a própria dinâmica da vida social e cultural, seus 


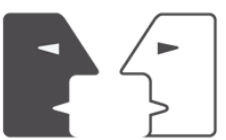

ANTÍTESES

conflitos, ambiguidades e paradoxos, assim como seus efeitos na subjetividade individual e coletiva (GONÇALVES, 2007, p.15).

As joias de crioulas, enquanto objetos da cultura material possuíam uma estética peculiar quanto à dimensão, ao peso, ao formato e à decoração, pois são joias de grandes proporções, embora geralmente sejam ocas, além de serem profusamente decoradas e usadas em quantidade pelas suas portadoras (Fig.3). Tais joias se opunham das utilizadas pelas senhoras brancas, que geralmente preferiam peças importadas da Europa ricamente decoradas com diamantes, pérolas e outras gemas (CUNHA; MILZ, 2011, p.46).

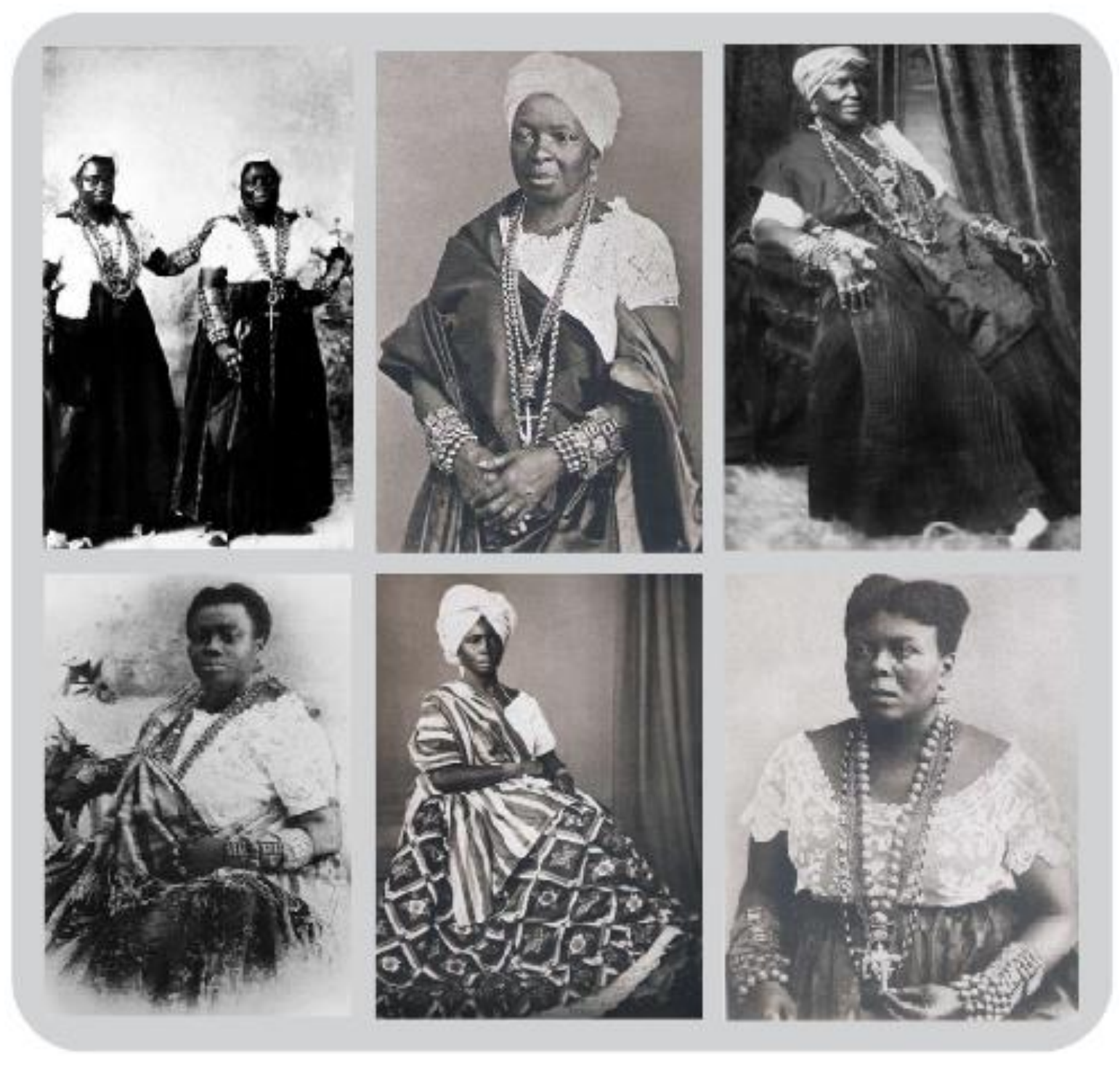

Figura 3: Mulheres negras portando exemplares da joalheria afrobrasileira.

Fonte: FACTUM, 2009, p.157, p.231, p.239, p.251, p.258 e p.298. 
Embora a sociedade do Brasil Colônia fosse hierárquica, os grupos tidos como "marginalizados" foram peças fundamentais neste panorama.

A escravidão [...] recentemente [...] adotou um ponto de vista processual, no qual a marginalidade e a ambiguidade de status se tornaram o centro da identidade social do escravo [...]. Sob essa perspectiva, a condição de escravo é vista não como um status fixo e unitário, mas como um processo de transformação social que envolve uma sucessão de fases e mudanças de status, alguns dos quais se fundem com outros status [...] que, nós, os ocidentais, consideramos muito distintos da escravidão (KOPYTOFF apud APPADURAI, 2008, p.90).

Um desses grupos que desempenhavam as mais diversas funções no espaço urbano, principalmente no comércio ambulante, foi o chamado negras(os) de $g a n h o^{4}$. As atividades que eles exerciam geralmente eram revertidas em lucro para seus senhores, que recebiam os ganhos por dia de atividade pública, a qual se dava, geralmente, em praças. Com o restante dos valores adquiridos, muitas delas acumulavam pecúlio a fim de comprar sua alforria. Como explica Lody,

${ }^{4}$ Trabalho, serviço, atividade com remuneração, comum no Brasil do século XIX, sendo exercida quase que exclusivamente por negros. Assim, ocorriam às vendas de comidas, bebidas, animais, objetos artesanais, além de ofícios como barbeiros, alfaiates, e carregadores de mercadorias e de pessoas (LODY 2001, p.19). 
A posse dessas joias representava para essas mulheres um indicativo de prosperidade, clientela numerosa e, portanto, sinal de que a ganhadeira vendia produtos de qualidade.

Ainda que Chica da Silva ${ }^{5}$ seja a mais famosa liberta bem sucedida durante o período escravocrata no Brasil, alguns documentos comprovam a existência de muitas outras negras, que também conseguiram notoriedade e ascensão social. Pesquisas afirmam que, depois dos homens brancos, muitas destas mulheres chegaram a acumular significativa riqueza material, gerando um invejável prestígio social. Assim, estas mulheres, compunham o grupo mais rico desta sociedade, pois, depois dos homens brancos, elas eram as que mais redigiam testamentos, como podemos observar na análise de Mott,

Maria da Costa [...] morou em São Caetano, aí registrando seu testamento em 1745. Era da nação Ardra (Porto Novo), solteira, tendo comprado sua alforria

por 190 oitavas de ouro. Em vez de imóveis, esta daomeana investiu primeiro em escravos: possuía nove cativos em idade economicamente ativa, com menos de 30 anos. Depois, aplicou seu capital em jóias de ouro. A vaidade ostentatória destas "Vênus de ébano" escandalizava os moralistas: o jesuíta italiano Giovanni António Andreoni (Antonil) já em 1711 denunciava os "excessivos gastos em cordões, argolas e outros brincos, dos quais se vêem hoje carregadas as mulatas de mal viver e as negras, muito mais que as senhoras". Maria da Costa parece ter servido de inspiração para tal comentário, pois em seu testamento declarou possuir os seguintes enfeites, todos em ouro: dois enormes cordões de pescoço, uma cruz, uma imagem de Nossa Senhora da Conceição, um Menino Jesus, um Espírito Santo, quatro pares de brincos, um anel de filigrana, seis pares de botões, vários braceletes e corais, perfazendo tudo mais de 600 gramas de ouro puro. Era mulher requintada também no vestir: mau grado o calor tropical da Comarca de Vila Rica, e a proibição real de que as negras usassem tecidos de gala, tinha uma grossa saia preta e um conjunto azul claro; tudo em precioso veludo, provavelmente importado de Flandres. Como liberta, adquirira o privilégio de andar calçada: trazia um par de fivelas de prata em seu sapato. Sua residência de telhas em São Caetano devia ser das casas de pasto mais sofisticadas da vila: seu serviço de mesa incluía sete colheres e um garfo de prata, seis

\footnotetext{
${ }^{5}$ A mais famosa das mulatas do período escravista, foi amante do homem mais rico do Reino, o desembargador João Fernandes de Oliveira. Chica representa em nossa consciência coletiva uma espécie de estereótipo final do itinerário possível das escravas no seu processo de alforria e ascensão social: personifica, o modelo viável, em sua concretização máxima, da mulher de cor que através de sua sensualidade inebriante cativa o coração e os sentidos dos brancos (Adaptado de MOTT, s/d, p.18-119).
} 
pratos de estanho, além de tachos de cobre, bacia de arame e demais trastes de casa. Suas roupas de cama e mesa eram o que de melhor existia na praça: quatro lençóis de linho, seis toalhas de renda, tudo conservado em rico baú de moscôvia (MOTT, s/d, p.121-122).

Outro caso que podemos citar é o de Bárbara Gomes de Abreu e Lima, uma crioula que saiu escravizada de Sergipe del Rei em direção às Minas, ao registrar parcialmente em cartório seus legados testamentais, os quais ela dizia possuir:

[...] seis cordões pesando cento e uma oitavas, um se acha empenhado na mão de Thereza de Jezus, mulher de Antonio Aves por vinte oitavas e três na mão de Jozé Ferreira Brazam donde se acham dois cordões emendados que fazem um, quarenta oitavas, um cordão com águia, um pente, uma estrela, uma argola solta, um coração, tudo em ouro, também empenhado na mão de Jozé Ferreira Brazam, um cordão de ouro, um feitio de menino Jesus de ouro pesando cinco oitavas, umas argolinhas de ouro pesando quatro oitavas, uma senhora de feitio de Nossa Senhora da Conceição pesando três oitavas e meia, uns brincos de aljôfar e uns botões de ouro, umas argolinhas de ouro pequenas, uma bola de âmbar, uma volta de corais engranzados em ouro, um coral grande com uma figa pendurada, tudo de ouro, quatro colheres de prata pesando oito oitavas cada uma, quatro garfos de prata e uma faca com cabo de prata, duas memórias de emberessadeiras (sic), dois pares de botões de anáguas abertos no buril, tudo empenhado na mão de Manoel de Magalhaens por sete oitavas, o que meus testamenteiros desempenharão. Item tenho empenhado mais um cordão de ouro com o peso que se achar na mão de Jozé Rodrigues de Souza por vinte oitavas que meus testamenteiros desempenharão. [...] um tacho grande de cobre e outro pequeno, doze pratos de estanho c dois grandes, uns corais, quatro saias, duas de seda preta e uma de rossa (sic) grana (sic) parda e uma de camelão e a roupa branca que se achar [...] três panos de dois côvados, um preto, um azul e um verde, um colchão de lã [...] (PAIVA, 2006, p.220-221).

Apesar das adversidades e dos diversos preconceitos que sofriam os testamentos e inventários mostram que estas mulheres sobrepujaram as barreiras e, mesmo mantendo os 
estigmas, andavam adornadas de joias e roupas de sedas, chocando e burlando a ordem vigente. $E$ através das vestimentas e das joias utilizadas pelas crioulas se deu a materialização de auto preservação das mesmas, haja vista que tais objetos simbolizavam a manutenção de sua cultura, mesmo adaptada, bem como a sua resistência à condição de mercadoria (FACTUM 2009, p.28), constituindo, assim, em um signo de poder social. Gonçalves (2007, p.21) sugere que:

[...] os objetos não apenas demarcam ou expressam tais posições e identidades, mas que na verdade, enquanto parte de um sistema de símbolos que é condição da vida social, organizam ou constituem o modo pelo qual os indivíduos e os grupos sociais experimentam subjetivamente suas identidades e status [...].

Nesta sociedade, a moda representava um dos meios de distinção, em que o uso de determinados signos sociais, incorporavam símbolos responsáveis por identificar funções, definir identidades e de assinalar as distâncias sociais entre os indivíduos da sociedade que era praticamente analfabeta, criando, assim, uma comunicação não verbal, em que o prazer de exibir-se ao olhar do outro era imprescindível em todas as camadas sociais.

Sinais exteriores da posição social dos indivíduos como vestuário e jóias tinham importante papel na hierarquizada sociedade brasileira do século XIX. Neste contexto a indumentária deve ser vista como importante elemento simbólico ao evidenciar as diferenças existentes entre os grupos sociais, tornando visível a hierarquia social. Além de definidora de identidades, a moda permitia a visualização sistemática de significados relacionados a valores e padrões de comportamento. A observação e análise de roupas e ornamentos facilitam a compreensão acerca das relações de poder existentes entre pobres e ricos, negros e brancos, escravos e libertos, bem como entre homens e mulheres (BITTENCOURT 2005, p.25).

Assim, as joias de crioulas também podem ser consideradas como uma das diversas formas de subversão, pois a rebeldia das(os) escravizadas(os) não se estabeleceu exclusivamente a partir de grandes atos coletivos, mas também de pequenas e cotidianas resistências. 
O impacto visual e social era tão grande, que a ostentação no trajar, de algumas escravizadas, incomodava diretamente a classe dominante, tanto que em 1636, foi estabelecida uma portaria real em que limitava este luxo:

El-Rei, tendo tomado conhecimento do luxo exagerado que as escravas do Estado do Brasil mostram no seu modo de vestir, e a fim de evitar este abuso e o mau exemplo que poderia seguir-se-lhe, Sua Majestade dignou-se decidir que elas não poderiam usar vestidos de seda nem de tecido de cambraia ou de holanda, com ou sem rendas, nem enfeites de ouro e de prata sobre seus vestuários (VERGER, 1992, p.103).

No entanto, essas leis suntuárias não foram respeitadas, e os senhores encontravam mais um meio para demonstrar sua riqueza ao adornar suas escravizadas, tornando-as como símbolos moventes de ostentação.

Quando, por exemplo, nas poucas vezes em que a senhora de família abastada saía às ruas, era acompanhada de suas escravas, vestidas de sedas e enfeitadas de joias. Se as senhoras brancas desfilavam em um cortejo reluzente em que tilintavam ouro e pedras preciosas, as escravas eram adornadas com várias vezes o próprio valor de sua alforria, mostrando o status de seu senhor (CUNHA; MILZ, 2011, p.152).

Em alguns casos, as joias eram presenteadas, como forma de agradecimento pelo "bom comportamento" destas. Neste sentido, Gonçalves (2007, p.27) aponta que "os objetos materiais estão submetidos a um processo permanente de circulação e reclassificação, podendo ser deslocados da condição de mercadoria para a condição de presentes; ou da condição de presentes para a condição de mercadorias".

Porém, tais características não podem ser empregadas a todas as mulheres negras, haja vista que as mulheres que trabalhavam na lavoura e habitavam a senzala vestiam-se de forma menos opulenta se comparadas às mulheres que desempenhavam a função de mucamas e habitavam a casa grande ou eram libertas. Essas indumentárias possuíam significados diversos. 
Na sua origem havia um duplo significado: para a usuária, uma ressignificação de si mesma, diante do lugar social reservado a sua condição de escrava, e, para a classe dominante, uma afirmação explícita do lugar do 'Outro' que relega a mulher negra a um lugar social subordinado (FACTUM 2009, p.232).

Outra característica importante são os sistemas de créditos realizados a partir da doação de joias, nas irmandades de pretos e pardos, como a Irmandade da Boa Morte ${ }^{6}$ da cidade de Cachoeira, no estado da Bahia, que, dentre as atividades que desenvolviam, podemos destacar, dentro do âmbito social, a concessão de dotes e ajuda para a compra de cartas de alforria para familiares e outras(os) entes.

No que se refere às técnicas empregadas para a confecção destas joias, podemos destacar a:

[...] incorporação de técnicas moçárabes como a filigrana ${ }^{7}$ em prata e ouro, bem como alguns modelos de correntões de pescoço, brincos e outros objetos de adorno corporal, a chamada joalheria crioula afrobrasileira sofreu ajuste em estilo, apoiando a caracterização da mulher africana, mulata ou crioula no Brasil (LODY, 1988, p.21-22).

Sabe-se que a participação dos negros, mestiços e indígenas era proibida no ofício da ourivesaria, como elucida Oliveira (1948, p.30):

No século XVII, um alvará de 20 de outubro de 1621, dizia que, nenhum mulato, negro ou índio, mesmo liberto, podia exercer o cargo de ourives; porém a necessidade da vida colonial levava o ourives a ter na sua oficina escravos ou forros, que os senhores empregavam, recebendo boa renda.

\footnotetext{
${ }^{6}$ Originada nos últimos anos do século XVIII, a Irmandade da Boa Morte - composta por mulheres negras de nação Keto e Gege e conhecidas como as Nagôs libertas da igreja da Barroquinha, logradouro localizado no seio da área central da cidade. Em suas obras destacam que esta confraria abrigava somente mulheres - organizadas pelos elos fraternos fomentados no cerne da lógica do movimento confraternial (CORRÊA, 2008, p.121).

${ }^{7}$ Espécie de renda de metal, feita de fios de ouro ou prata delicadamente soldados, com ou sem decoração em grânulos, compondo arabescos e outros motivos (GOLA, 2008, p.205).
} 
Isso prova que as minas descobertas tinham estimulado a arte da ourivesaria.

O que também fica evidenciado na análise de Paiva (2006, p.235):

É bem possível que tenham existido ourives especialistas na elaboração dessas jóias- amuletos consumidos em larga escala. Vários desses ourives tinham aprendizes escravos e forros, alguns artesãos eram, eles próprios, ex-escravos e quase todos eram iniciados em cultos afrobrasileiros ou conheciam os signos e símbolos agregados às manifestações religiosas de escravos, forros e seus descendentes. Não foram poucos os africanos artífices do ouro que entraram escravizados e trabalharam em varias regiões da Colônia. O trabalho de todos eles possibilitou a injeção de valores culturais, de objetos e de material africanos e afro-brasileiros na ourivesaria colonial e facilitou, também, a apropriação de emblemas, representações e estéticas europeias pela população negra e mestiça.

De acordo com Factum (2009, p.28), as joias de crioulas são consideradas um produto do hibridismo cultural ao serem compostas por artefatos híbridos ${ }^{8}$ na sua aparência, na mistura de heranças culturais variadas e nas técnicas de produção, além de não poderem ser classificadas unicamente como européias ou africanas, possuindo contribuições de estilos variados como o: barroco ${ }^{9}$, rococó $^{10}$, neoclássico ${ }^{11}$, aliados a concepção formal africana, o que possibilita nomeá-las como joias afro-brasileiras.

\footnotetext{
${ }^{8}$ De acordo com Canclini (2006, p.19) o conceito de hibridação consiste em "processos socioculturais nos quais estruturas ou práticas discretas, que existiam de forma separada, se combinam para gerar novas estruturas, objetos e práticas".

9 "A arte barroca (1600-1750) conseguiu casar a técnica avançada e o grande porte da Renascença com a emoção, a intensidade e a dramaticidade do Maneirismo, fazendo do estilo barroco o mais suntuoso e ornamentado na história da arte" (STRICKLAND, 2004, p.46).

10 "O Rococó nasceu em Paris, coincidindo com o reinado de Luís XV (1723-74) [...] Até o final do século continuou a ornamentar luxuosos castelos e igrejas da Alemanha, da Áustria e da Europa Central. O nome rococó é derivado de rocaille, referente a conchas e seixos que ornamentam grotas e fontes, e surgiu como um estilo de decoração de interiores" (STRICKLAND, 2004, p.64).

11 "Mais ou menos a partir de 1780 até 1820 , a arte neoclássica refletiu [...] o austero Classicismo na pintura, na escultura, na arquitetura e no mobiliário constituiu uma clara reação contra o enfeitado estilo rococó” (STRICKLAND, 2004, p.68).
} 


\section{Exemplares de Joias de Crioulas}

\section{Bracelete Copo:}

Os braceletes copos (Fig.4) são denominados assim devido à sua forma e tamanho. Também são chamados de braceletes punho, são compostos por duas ou quatro placas, unidas entre si por articulações. Cada placa é formada por uma chapa central de metal, geralmente em ouro, estampada ou com filigranas. Os braceletes eram decorados com efígies masculinas e femininas, de feições africanas ou europeias, frequentemente eram retratos dos imperadores e imperatrizes.

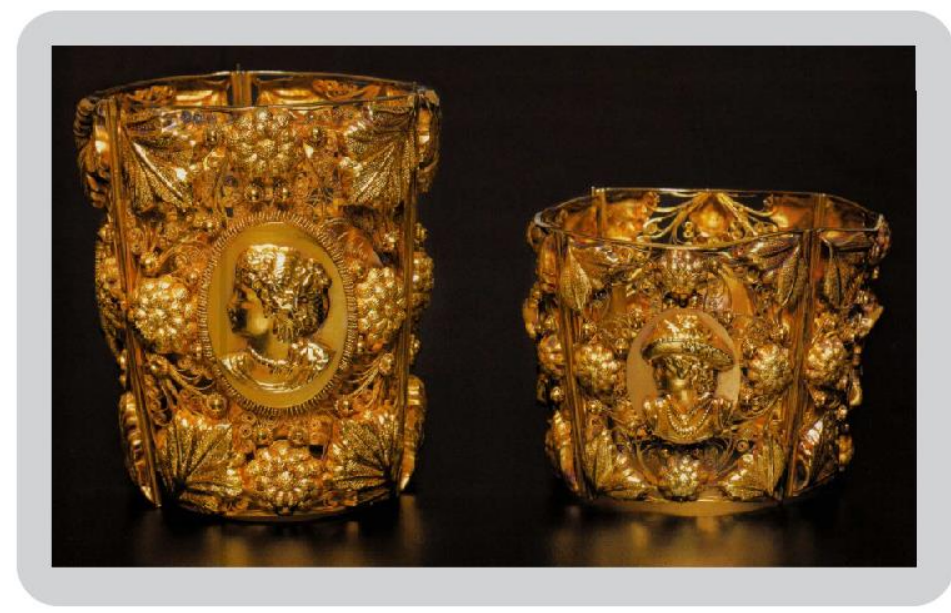

Figura 4: Braceletes em ouro. Fonte: SILVA, 2012, p.23.

Ao analisarmos a peça, observamos que a concepção formal da pulseira possui matriz africana, apesar dos muitos elementos europeus como a representação de folhas de acanto e flores, volutas em filigranas, utilização da técnica do granulado ${ }^{12}$, bem como a efígie de uma mulher de perfil, característica presente na joalheria neoclássica (FACTUM, 2009, p.161).

\section{Pulseira de placas:}

Estas pulseiras são formadas por várias placas retangulares ornamentadas com motivos fitomorfos ou efígies (Fig.5). Sua união se dá por fileiras de três ou mais

\footnotetext{
${ }^{12}$ Técnica em que se adicionam "grânulos redondos de metal por fusão (costumeiramente não por solda) para criar relevo em linhas, padrões ou formas" (GOLA, 2008, p.205).
} 
cilindros no mesmo metal, vidro ou $\operatorname{coral}^{13}$, que foram frequentemente utilizados na composição das Joias de Crioulas, pois, de acordo com Januário, "O coral era a pedra de Oxum e quem a usava se sentia fortalecido com os seus poderes e ao mesmo tempo protegido de todas as forças contrárias a este deus" (2003, p.5). 0 estilo neoclássico francês também está presente no que se refere a termos de culto à personalidade, onde era esculpida, em baixo-relevo as efígies de D. Pedro I, D. Pedro II e D. João VI:

$\mathrm{Na}$ Bahia predominavam as pulseiras de ouro compostas de seções retangulares tendo ao centro efígies masculinas e femininas, retratos dos imperadores e imperatrizes. Por ocasião da menoridade de D. Pedro, eram comuns as pulseiras com efígies do imperador menino (OLIVEIRA apud FACTUM 2009, p.163).

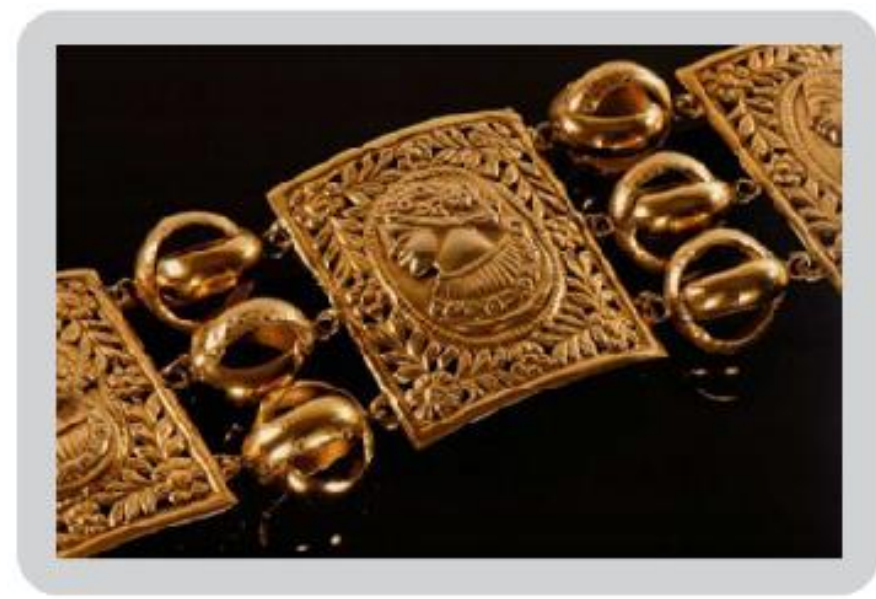

Figura 5: Detalhe de pulseira de placa, em que as placas centrais, confeccionadas com ouro estampado, são unidas por alianças entrelaçadas.

Fonte: CUNHA; MILZ, 2011, p.76.

Portar as representações dos membros da família real do Brasil nas joias era uma característica do período, haja vista que era necessário conceder significados sociais a estas joias, pois elas faziam parte do projeto de inserção social de suas portadoras.

\footnotetext{
13 “O coral é um material orgânico marinho explorado no Mediterrâneo (Itália, Espanha, Argélia, Tunísia) e no Oceano Índico e foi trazido destas regiões pelos portugueses no século XV, sendo comercializado em toda a Europa e no continente africano. Esta peça tornou-se cara e preciosa para os africanos, que a ela atribuíram propriedades mágicas, místicas etc." (PAIVA, 2001, p.224).
} 


\section{Colares:}

As $\operatorname{contas}^{14}$ foram peças importantes da ourivesaria baiana, sendo utilizadas em pulseiras e colares (Fig.6). Geralmente redondas essas joias podiam ser lisas ou confeitadas com filigranas e pequenos grãos de ouro, com formas e tamanhos variados. A sequência de contas formam pulseiras e colares que possuíam tamanhos variados e eram utilizados como adornos ou de uso devocional.

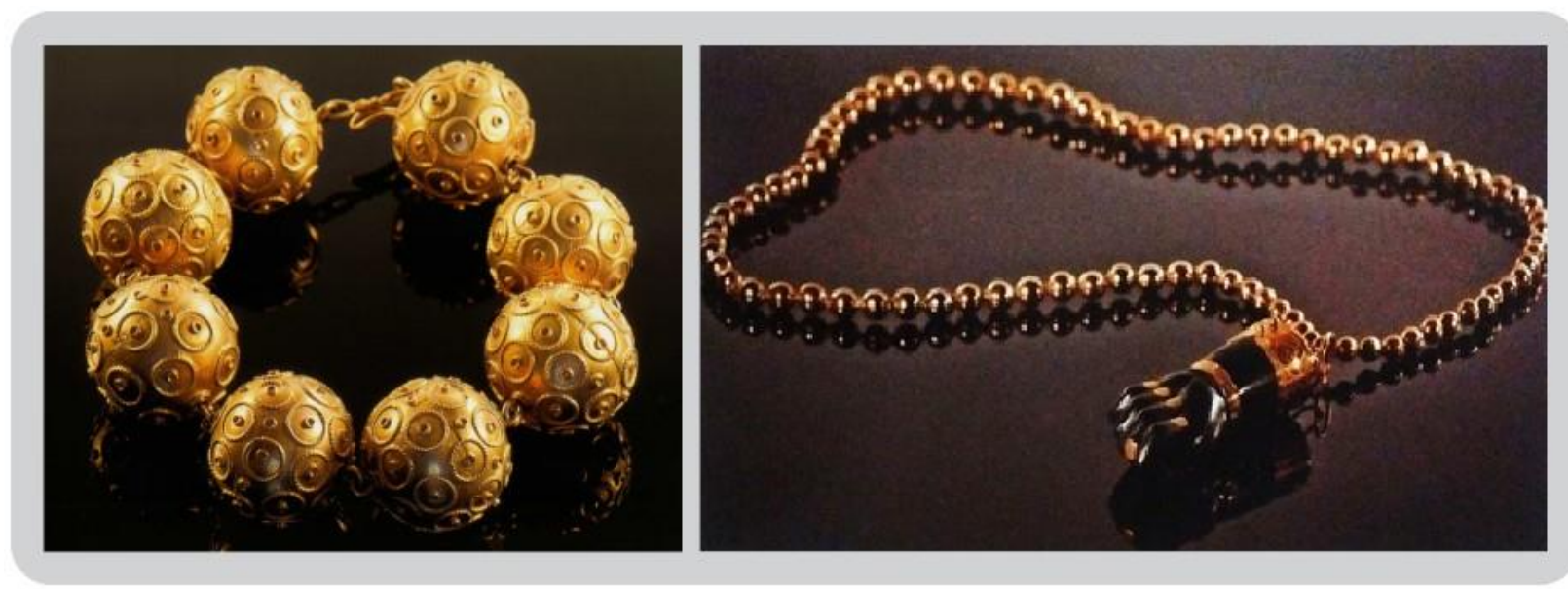

Figura 6: Pulseira feita com contas confeitadas e correntão de contas lisas com figa de ébano e ouro Fonte: CUNHA; MILZ, 2011, p.89 e p. 91.

O uso das contas pelas mulheres negras ou mestiças no Brasil possui a influência dos costumes das mulheres brancas brasileiras e/ou portuguesas.

Interligações existentes entre Portugal, África e Brasil através dessas jóias raras, exuberantes e de significado até hoje pouco conhecido. As jóias de crioulas baianas guardam semelhança com as jóias africanas akan, mas também com jóias populares portuguesas no Noroeste de Portugal e com jóias da Martinica (GODOY apud FACTUM, 2009, p.169170).

14 "Conta é uma designação geral para tudo que é processado por enfiamento com a finalidade de ser um fio-de-contas" (LODY, 2001, p.63). 
Os correntões de contas confeitadas foram muito populares entre as crioulas. Chegavam a medir mais de um metro e meio de comprimento. Em alguns exemplares, era comum pender da corrente uma peça de ouro, que podia ser uma figa, um coração, uma rosácea ou um crucifixo (Fig.7). Em outros correntões menores, as contas de ouro são associadas a cilindros de coral.

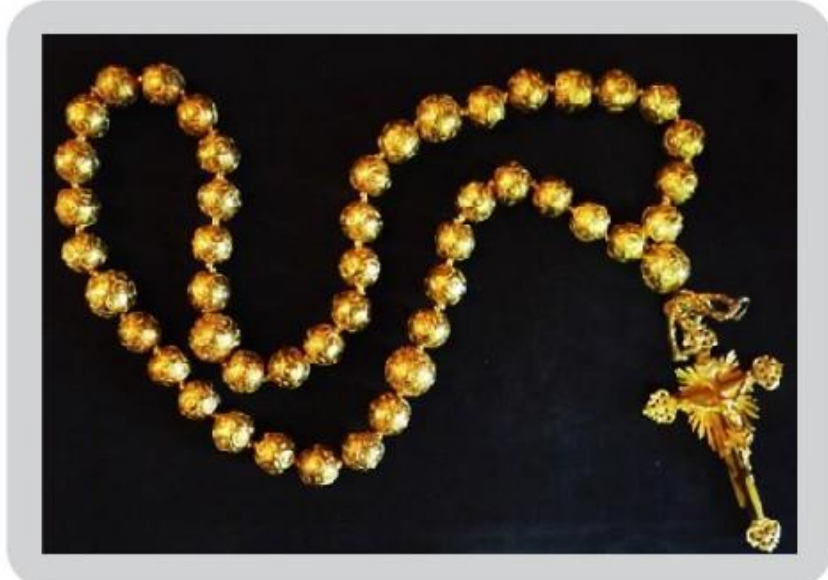

Figura 7: Correntão feito com contas confeitadas e pendente em forma de cruz de raios. Fonte: Autora, 2014.

O colar de alianças, grilhões ou correntões cachoeiranos, geralmente eram formados pelo encadeamento de elos em formato de alianças que podem ser lisas ou decoradas, que se entrelaçam. Alguns exemplares também trazem pendentes com símbolos católicos (Fig. 8).

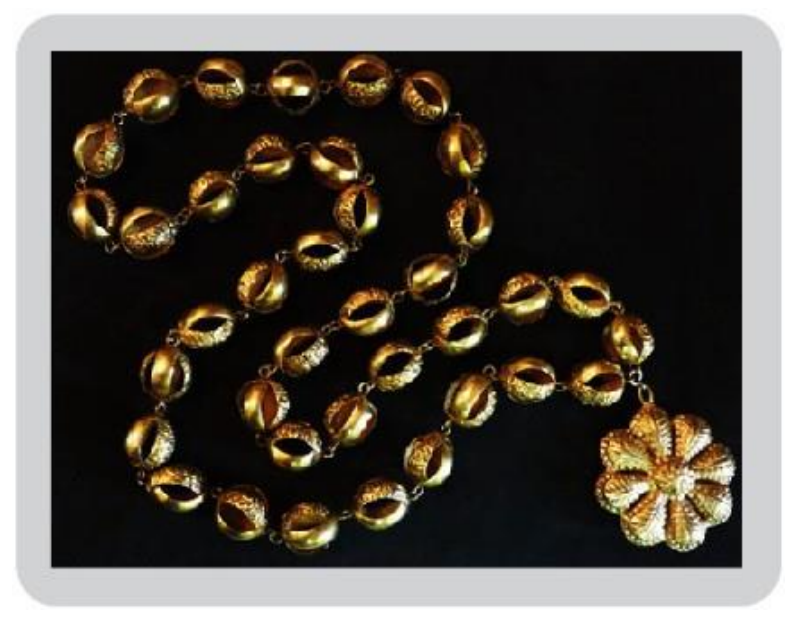

Figura 8: Correntão de alianças lisas e decoradas com pendente de roseta, ambos em ouro. Fonte: Autora, 2014. 
De acordo com a tradição, "cada elo é originário de uma aliança portuguesa conquistada após uma noite de amor" (Lody, 2001, p.51). O "favor sexual" envolvido na posse das joias pelas escravizadas remete ao fato de existirem outras atividades de ganho que não se relacionavam com a venda de objetos ou de alimentos, e sim à prostituição.

\section{Brincos:}

Os brincos eram indispensáveis na composição da indumentária das crioulas e um dos mais tradicionais são os do tipo "pitanga", seu nome se dá pela semelhança de sua forma com a fruta (Fig.9). De acordo com Cunha e Milz (2011, p.113), "esses brincos eram de ouro ou prata, sempre com uma grande peça central, frequentemente em ágata ${ }^{15}$, coral, conta de vidro ou metal". Enquanto outros modelos possuíam contas na sua composição,

[...] alguns seguindo modelos tradicionais afro-baianos, como barrilzinho - conta cilíndrica em torno de $2 \mathrm{~cm}$ de comprimento e $1 \mathrm{~cm}$ de diâmetro, com variantes, sendo geralmente uma firma rajada bicolor, uma firma africana, um coral verdadeiro, ente outras (Lody, 2001, p.113).
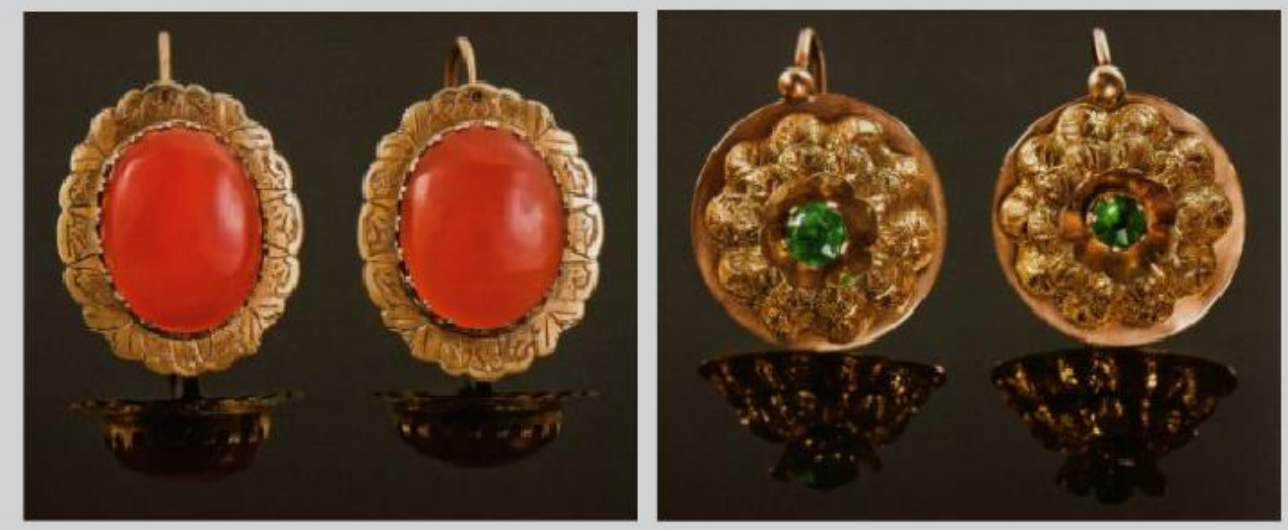

Figura 9: Brinco com cornalina em lapidação cabochão oval e brinco com vidro verde lapidado em facetas Fonte: CUNHA; MILZ, 2011, p.112.

\footnotetext{
15 "Quartzo lapídio, duro, translúcido e com franjas ou capas e diversas cores ou tonalidades. [...] Polidas, convertem-se em
} belas pedras semi-preciosas, muito utilizadas em joalheria” (GIL, 2006, p. 68). 
Outros modelos de contas para brincos são produzidos em louça ou vidro e na forma redonda, em uma única cor ou possuindo detalhes representando significados para sua portadora, sempre em uma correspondência imediata aos fios-de-contas ${ }^{16}$.

\section{Anéis:}

Muitos dos anéis usados pelas crioulas apresentavam características da talha barroca, (Fig.10) "tanto as jóias escravas baianas como as jóias populares portuguesas perseguiam o mimetismo com a decoração das igrejas de forma tão intensa que nos leva a conjecturar ser uma busca a sua consagração, talvez uma razão a mais para este perfil da arte barroca" (FACTUM, 2009, p.174). Outros exemplares apresentam uma concepção híbrida, em que a base do anel segue o estilo da talha dourada barroca e seu topo central é em metal oxidado e pedra branca, geralmente um diamante ou uma safira branca, característico da joia vitoriana.
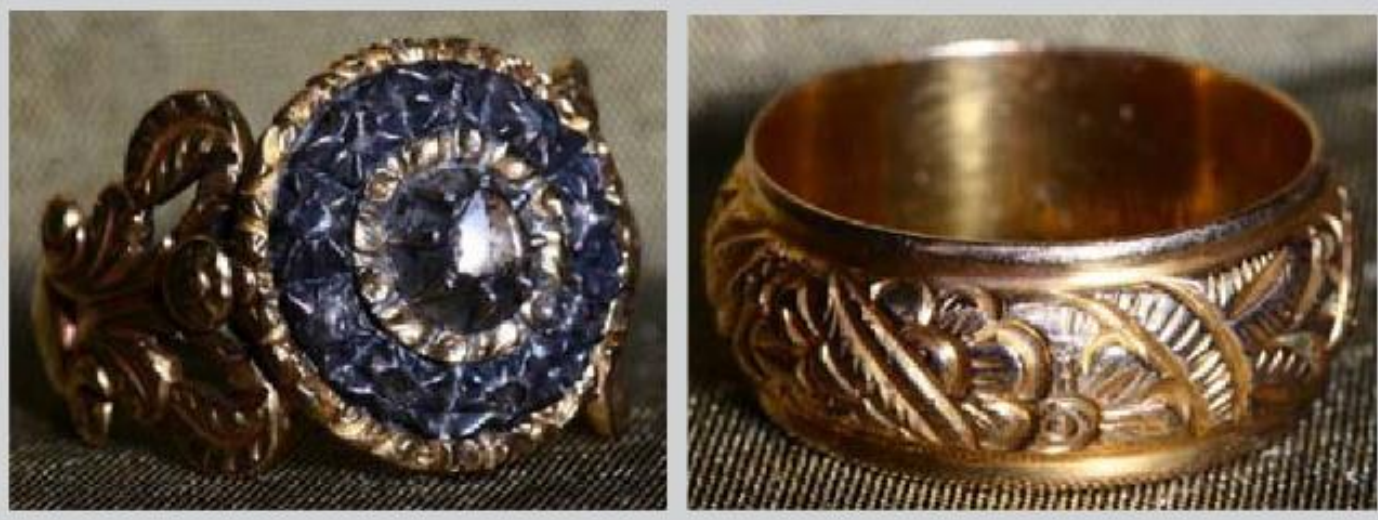

Figura 10: Anéis usados pelas crioulas Fonte: FACTUM, 2009, p.173.

\section{Pencas de Balangandãs:}

Dentre as peças de joalheria afro-brasileiras, as pencas de balangandãs (Fig.11) ocupam posição destacada, devido a sua singularidade e por ser uma joia exclusivamente brasileira.

16 "O fio-de-contas é emblema social e religioso que marca um compromisso ético e cultural entre o homem e o santo. É um objeto de uso cotidiano, público, situando o indivíduo na sociedade do terreiro. Há critérios que compõem os textos visuais dos fios-de-contas, proporcionando identificação de santos, papéis sociais, rituais de passagem - o quelê -, ou ainda fiosde-contas mais sofisticados, que, além de identificar o indivíduo, sua atuação no terreiro, ainda identifica o tipo de Nação, ora por cor, ora por emblema [...]" (LODY, 2001, p.59). 


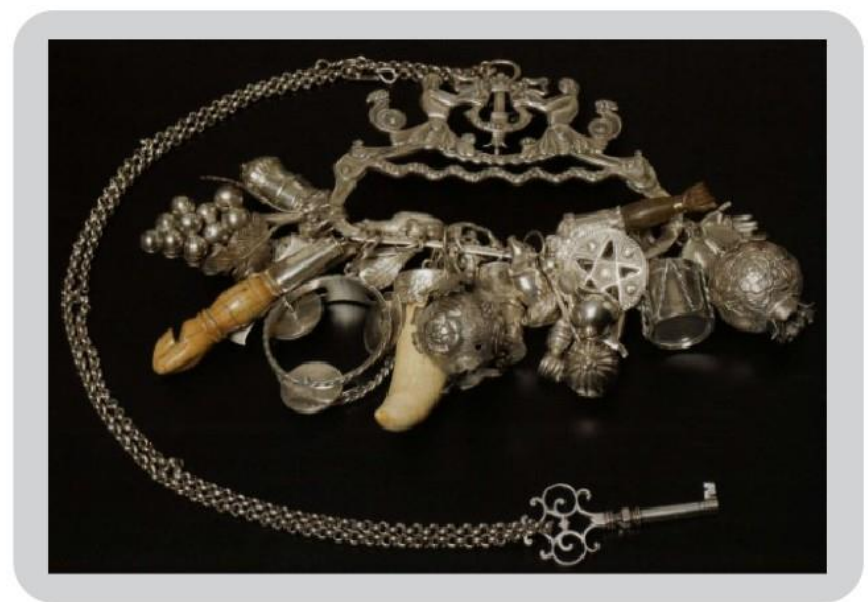

Figura 11: Pencas de balangandãs em prata com 27 peças e corrente. Fonte: SILVA, 2012, p.28.

Geralmente, essas joias eram usadas na cintura, por ser a zona que marca a fertilidade e, consequentemente, por possuir um grande significado ritual religioso. Sua disposição davase por meio de argolas individuais ou tiras de couro ou ainda outros materiais, em que cada peça continha cerca de 20 a 50 objetos. Eram altamente movimentados e sonoros ao se chocarem uns com os outros, tanto que lhe conferiu uma denominação de referência onomatopaica para muitos estudiosos do tema. Logo, esse potencial sonoro é inerente à sua composição, haja vista que diversos amuletos possuem a função de "espantar" as influências malignas através do som.

As pencas de balangandãs eram confeccionadas em metal, comumente em prata, reunindo pendentes com formas variadas, como: búzios, moedas, figas, chaves, dentes de animais, representações de frutas, entre outros símbolos. Estes são agrupados em uma base denominada "nave". Os elementos que compõe as pencas de balangandãs são reunidos em função de seus significados mágicos e rituais.

Os balangandãs são considerados amuletos que supostamente afastam "mau-olhado", trazem sorte ou indicam "riqueza". Originalmente, o uso de adornos, esteve ligado a essa função, o que já era comum desde épocas pré-históricas, costumando ser um objeto de pequenas dimensões, quase sempre carregado junto ao corpo.

[...] outro modo de invocar a proteção dos poderes é o uso de amuletos (também chamados fetiches). Acredita-se que o amuleto é a seda do poder mágico ou que ele talvez seja o símbolo desse poder, e a sua ação pode basear-se no seu significado simbólico [...] Acredita-se que tais objetos estão investidos de poderes sagrados [...] que supostamente têm o poder de afastar os espíritos (BOAS, 2004, p.318 - 319). 
Existem figuras predominantes entre os amuletos, como: chifres, pimentas, trevos, figas, olhos gregos, efígies de santinhos (ou outra entidade, dependendo da sociedade), e pedras preciosas às quais se atribuem certos poderes. Esses amuletos eram ritualmente sacralizados, sendo impregnados de propriedades supostamente mágicas, de modo que o objeto desempenhe seu papel de símbolo possuidor de valores mágicos, para finalmente serem utilizados nas ruas.

Embora alguns autores apontem suas semelhanças com o châtelaine ${ }^{17}$ e com molhos de objetos usados por mulheres nômades na África islamizada, a penca de balangandãs também apresenta semelhanças estéticas com a ferramenta de Ogum (Fig.12).

Este orixá é um deus da guerra e o seu fetiche é um fragmento de ferro, na África e entre os negros da América Latina. Ainda mais: como uma divindade das lutas, carrega consigo os seus apetrechos bélicos de ferro (espada, foice, lança, pá, enxada, etc.), chamados na Bahia a ferramenta de Ogum (RAMOS, 1940, p.41).

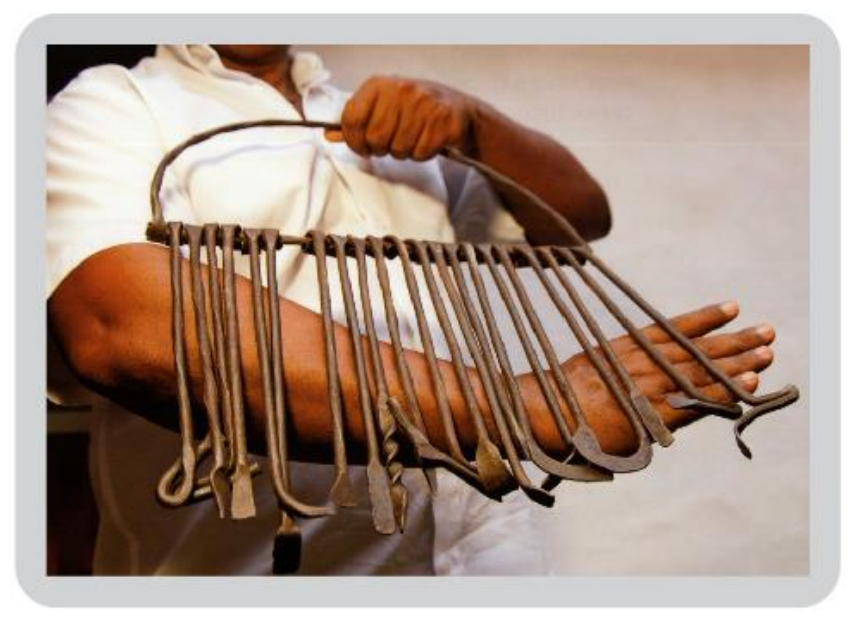

Figura 12: Ferramenta de Ogum. Fonte: CUNHA; MILZ, 2011, p.120.

17 “O châtelaine era o molho de chaves preso à cintura das donas de casas francesas, que se tornou habitual no Brasil até o início do século XX. [...] O molho dessas chaves era sempre mantido junto à cintura da sinhá, preso por uma argola, por questões de praticidade e segurança. Com o passar do tempo, agregaram-se outros objetos ao molho, como relógios, pequenas tesouras e toda a sorte de pequenos utensílios de uso cotidiano, além, é claro, de objetos devocionais como medalhas de santos" (CUNHA; MILZ, 2011, p.122). 
Sabemos que o quadro cultural do Período Colonial Brasileiro era composto por diversas tradições, oriundas de etnias diferentes, das quais surgiram práticas crioulas marcadamente sincréticas.

Assim, ocorreu a dinâmica de mutação cultural ao sugerir um processo de ressemantização sígnica.

De todas as instituições africanas, entretidas na América pelos colonos negros ou transmitidas aos seus descendentes puros ou mestiços, foram as práticas religiosas do seu fetichismo as que melhor se conservaram no Brasil. No entanto, não se poderia admitir que mesmo entre os africanos as crenças religiosas dos negros aqui pudessem revestir em absoluto as formas múltiplas e variadas por que se manifestam na África (RODRIGUES, 1977, p.214).

Aparentemente, o negro aceitou o catolicismo pregado pelos missionários, mas na sua incapacidade psicológica de abstração, na incompreensão, portanto, do monoteísmo, ele incorporou o catolicismo ao seu sistema mítico-religioso, transformando-se assim o fetichismo numa vasta religião politeísta, onde os orixás foram confundidos com os santos da nova religião que lhe foi ensinada (RAMOS, 1940, p.129).

Dessa forma, a religião era o campo propício para a manifestação dessas práticas.

As religiões, comumente chamadas candomblés, significaram, portanto, uma defesa cultural para os africanos e seus descendentes, muito embora esporadicamente delas participassem brancos; por seu intermédio, salvaguardavam as maneiras de ser e pensar que constituíam seu patrimônio específico [...] (QUEIROZ, 1989, p.20-21).

É neste cenário social e religioso que as peças que compunham as pencas de balangandãs conseguiram materializar seu hibridismo cultural. 
O objeto, ou a coisa mesmo, que circula enquanto algo praticado e ritualizado no corpo do social, mediante os atos que o fazem percorrer os complexos (des)caminhos da vida em sociedade, está repleto de sentidos e nexos compartilhados por aqueles que lhe atribuem valores e simbolismos, sendo que os mesmos emergem da própria experiência intersubjetiva das pessoas em interação entre si, e delas com o mundo. $O$ objeto encerra sempre uma dimensão ético-estética, remetendo ao gesto humano de criar, confeccionar e operar com os mais variados objetos em lugares específicos (SILVEIRA; LIMA FILHO, 2005, p. 38).

Nem todas as peças que compõem a penca são de origem africana ou afro-brasileira, pois alguns objetos, como os santos e símbolos do catolicismo, foram absorvidos e relidos, o que gerou um forte sincretismo aliado aos signos referentes à África, seu imaginário, orixás e superstições, adquirindo novos valores simbólicos.

Símbolos cristãos: a pomba ou os santos mártires ou todos os santos, como o galo, também representando a vigilância, a pomba do Espírito Santo, de asas abertas e a cruz feita com a cabeça e a cauda. São Jorge ou Oxocê, santo guerreiro e caçador, é representado pela lua, pela espada, pelo cão, pelo veado. São Jerônimo ou Xangô se representa pelo burro, pelo carneiro, pelo caju, o abacaxi e o milho. Santo Antonio, ou Ogum, pela faca, pelo porco. São Lázaro ou Omolu é representado pelo cão ou a fidelidade, e, às vezes, também pelo porco. São Cosme e São Damião se representam pela moringa d'água. Santo Isidoro ou Omolu moço (São Lázaro) contenta-se com o boi. São Bartolomeu no culto 'caboclo' tem o sol. Sant'Ana, ou mestra da Virgem, Nanã, tem por símbolo a palmatória. Nossa Senhora da Conceição ou Oxum fica com as uvas. A ferradura é o signo da felicidade; o coração, da paixão, se tem chamas, paixão ardente; as mãos dadas, da amizade; a romã é a humanidade (PEIXOTO, s/d, 278279 apud LODY 2001, p.54).

Quanto à classificação dos elementos pendentes da penca de balangandã, Menezes de Oliva (1957) determina cinco categorias, baseadas na utilidade ou função, são elas: 
Devocionais: os dedicados a um santo ou culto, como cruz, crucifixo, relicário, medalha. Votivos: os que representam o pagamento de uma promessa feita, como cabeça, perna, casa, olhos de santa Luzia. Propiciatórios: usados para atrair boa sorte, imunizando seu possuidor de infortúnios. Nesta categoria estão o signo Salomão, as moedas, os dentes, as figas. Evocativos: os que lembram fato decorrido, como o cacho de uvas, que lembra ao português a festa da vindima, o tambor que lembra a África. Decorativo: 'todo e qualquer outro dixe, que não pode ser, desde logo, incluído nas quatro primeiras categorias' como bolas coloridas (apud SILVA, 2005, p. 97).

Suas inúmeras combinações tornam cada penca única, visto que a peça é originária de escolhas pessoais de sua portadora. Sua característica aglutinadora poderia ser atualizada pela incorporação de novos elementos e exclusão dos existentes (como a venda por uma necessidade monetária). Ainda que não possuam vinculação mágica enquanto elementos isolados, podem compartilhar dessa intenção como elemento quantitativo, como afirma Bastide (1985, p.382):

O pensamento mágico é regido pela lei da acumulação, da intensidade e da adição. Desta forma, ocorre tanto o sincretismo, incorporação de elementos de diferentes tradições, como a ação da lei da contiguidade, onde elementos não mágicos se tornam mágicos por contágio (apud SILVA 2005, p.220).

Logo, a reapropriação de símbolos, segundo seus próprios critérios, surge como elemento fundamental no que tange à busca da identidade dessas mulheres escravizadas, ao procurarem, nas suas "raízes", o fundamento daquilo que as define de forma autêntica, repousando no sentimento de "fazer parte" desta sociedade, mesmo que de forma camuflada.

Assim, a penca de balangandã possuía um forte caráter religioso, por ser um meio de permissão para que as escravizadas declarassem sua religião oficial, mesmo que só aparentemente. Essa peça foi primeiramente identificada nos trajes das negras do "ganho" em praças públicas em Salvador no século XIX. Seu uso se deu principalmente entre as mulheres vendedoras que as usavam como protetores do dinheiro e do "ganho" e também no traje de beca das crioulas em dias festivos. Neste sentido, as joias adquirem funções de “objetos cerimoniais", os quais, segundo Gonçalves (2007, p.21), "[...] não apenas demarcam 
posições sociais, mas permitem que os indivíduos e os grupos sociais percebam e experimentem subjetivamente suas posições e identidades como algo tão real e concreto quanto os objetos materiais que os simbolizam".

Com o passar do tempo, essas pencas de balangandãs sofreram uma miniaturização e passaram a compor broches e pulseiras, além de serem produzidas em larga escala, sendo vendidas como lembranças da Bahia, ao plasmarem o conceito de símbolo do "Brasil Negro", aliado diretamente à figura do baiano.

Hoje se continua a fabricar pencas, algumas em prata e a maioria em alpaca, encontrando-se também em latão dourado e mesmo em cobre, porém desvinculadas das roupas. São empregadas no adorno de ambientes, o que faz com que os objetos aumentem de tamanho, constando obrigatoriamente alguns tipos como: figa, coco d'água, romã, cacho de uvas, abacaxi e outras frutas tropicais como o caju, por exemplo.

Os modelos seguem uma visualidade das peças tradicionais, porém apresentando tratamento artesanal sem o esmero dos prateiros e ourives baianos. É produção seriada para atender ao consumo de turistas que encontram nas pencas um dos símbolos mais fortes do "típico baiano", onde se combinam o berimbau e a boneca vestindo a roupa baiana (LODY, 1988, p. 28).

Com isso, as simbologias dessas joias produzidas no Brasil Colonial se perderam. Seus significados, que iam além de seus ícones, chega à contemporaneidade como referências históricas; suas funções religiosas como "crendices populares", e sua magia é tratada como curiosidades. Neste sentido,

[...] a difusão maciça de bens de consumo como atos de simbolização atingiu tal nível que, enquanto antigamente os bens representavam pessoas e relações, por exemplo, simbolizando classe e gênero, eles agora vinham a substituí-los. [...] [Tornando o] mundo moderno como um circuito sem fim de "signos" supérfluos levando a uma existência pós-moderna superficial que perdeu autenticidade e raízes (MILLER, 2007, p.37). 
Assim, estes objetos, que hoje são facilmente encontrados no comércio de Salvador, tornam-se uma referência vaga de todos os diversos significados de uso pelas mulheres que utilizavam os seus respectivos corpos como suporte sígnico, ao portarem estas joias, as quais contribuíram em uma das estratégias do seu processo de identidade, ao materializarem, nestes pequenos objetos a grandiosidade da rememoração de suas vivências passadas.

\section{Considerações finais}

Os objetos referem-se às diversas modalidades de significados criados pelo ser humano. Por meio de simbologias e signos, estas "coisas" materializam códigos culturais estabelecidos para fins de reconhecimento diante do seu meio social. Os objetos também são responsáveis na constituição de identidade, seja ela individual ou coletiva. Nesse sentido, as joias de crioulas afro-brasileiras desempenharam esta função, sendo um exemplar de materialização de uma das diversas formas de resistência ao regime escravocrata, que se manteve por mais de 300 anos vigente no Brasil. Tanto as joias quanto as vestimentas constituíram sinais exteriores da posição social dos indivíduos nos séculos XVIII e XIX. Portanto, estes foram elementos simbólicos que tornaram visível a hierarquia social. Também podemos afirmar que as joias, independente do período histórico, são suportes indicativos de valores, de tradições, rituais, crenças, desenvolvimento tecnológico, entre outros elementos culturais.

Sabemos que, quando homens e mulheres foram arrancados de forma brutal da sua terra natal para serem escravizados em outros países, estes passaram por um processo de subtração de identidade étnica, e consequentemente, traziam a necessidade latente de reconstrução. De acordo com a tese das tradições inventadas, Hobsbawm (2002, p.13) afirma que "houve adaptação quando foi necessário conservar velhos costumes em condições novas ou usar velhos modelos para novos fins". Dessa forma, a cultura objetificada negra no Brasil, neste caso as "joias de crioulas", exerceram perfeitamente este papel, ao incorporarem elementos e códigos europeus do colonizador aliados à estética peculiar destas joias.

Logo, as joias, para as crioulas afro-brasileiras, facilitavam a circulação de símbolos que expressavam resistência ao regime a que eram submetidas, tornando-se subterfúgios para sobreviver na sociedade do Período Colonial Brasileiro. Em suma, podemos ressaltar alguns de seus inúmeros significados: estratégia de ascensão social; sistema de créditos; devoções ocultas; herança de suas culturas e crenças de origem; poder e prestígio social; investimento e entesouramento; forte significado religioso e meio de proteção espiritual do corpo; símbolo da manutenção de sua cultura, mesmo que adaptada; preservação da autoestima; resistência à condição de mercadoria; reconstrução identitária; meio de conseguirem sua liberdade, entre outros elementos socioculturais. 


\section{Referências}

BITTENCOURT, Renata. Modos de negra, modos de branca: o retrato "baiana" a imagem da mulher na arte do século XIX. Dissertação (Mestrado em História da Arte e da Cultura) Universidade Estatual de Campinas, Campinas, 2005.

BOAS, Franz. A Religião dos Índios Americanos. In: A Formação da Antropologia Americana (1883-1911): Antologia. Rio de Janeiro: Contraponto/EdUFRJ, 2004.

CANCLINI, Nestor Garcia. Culturas Híbridas. São Paulo: EDUSP, 2006.

CORRÊA, Aureanice de Mello. Territorialidade e Simbologia: o corpo como suporte sígnico, estratégia do processo identitário da Irmandade da Boa Morte. Revista Brasileira de História das Religiões- Dossiê Identidades Religiosas e História, Maringá, Vol.01, n.1, p. 121-133.

CUNHA, Laura; MILZ, Thomas. Joias de crioula. São Paulo: Editora Terceiro Nome, 2011.

FACTUM, Ana. Beatriz Simon. Joalheria escrava baiana: a construção histórica do design de jóias brasileiro. Tese (Doutorado em Arquitetura e Urbanismo) - Universidade de São Paulo, São Paulo, 2009.

GIL, Santiago Alcolea e colaboradores. Artes Decorativas III: As artes decorativas aplicadas à indumentária e ao ornamento pessoal. Rio de janeiro: Edições Del Prado, 2006.

GOLA, Eliana. A jóia: história e design. São Paulo: Editora Senac São Paulo, 2008.

GONÇALVES, José Reginaldo Santos. Antropologia dos objetos: coleções, museus e patrimônios. Rio de Janeiro: Museu, memória e cidadania, 2007.

HOBSBAWM, Eric; RANGER, Terence. A Invenção das Tradições. Rio de Janeiro: Paz e Terra, 2002.

JANUÁRIO, Erlaine Aparecida. Jóias de adorno, como investimento e de devoção. Disponível em: <http://www.ichs.ufop.br/memorial/trab/h8_4.pdf> Acesso em: 20 de maio de 2017.

KOPYTOFF, Igor. A biografia cultural das coisas. In: APPADURAI, Arjun. A vida social das coisas: as mercadorias sob uma perspectiva cultural. Niterói: Editora da Universidade Federal Fluminense, 2008.

LODY, Raul. Pencas de Balangandãs da Bahia. Rio de Janeiro: FUNARTE/Instituto Nacional do Folclore, 1988.

. Jóias de Axé: fios de contas e outros adornos do corpo; a joalheria afro-brasileira. Rio de Janeiro: Bertrand Brasil, 2001. 
MILLER, Daniel. Consumo como cultura material. Horizontes Antropológicos, Porto Alegre, Vol.13, n.28, p.33-63.

MOTT, Luiz. De escravas à Senhoras. Disponível em: <http://www.ub.edu/afroamerica/EAV2/mott.pdf> Acesso em: 29 de maio de 2017.

OLIVEIRA, Octávia Corrêa dos Santos. Ourivesaria brasileira. Anais do Museu Histórico Nacional. Rio de Janeiro, Vol. IX, 1948.

PAIVA, Eduardo França. Escravidão e universo cultural na colônia: Minas Gerais, 1716-1789. Belo Horizonte: UFMG, 2006.

RAMOS, Arthur. O Negro Brasileiro. $3^{\text {a }}$ ed. São Paulo: Companhia Editora Nacional. 1940.

REIS, João José. Rebelião escrava no Brasil: a história do levante dos malês em 1835. São Paulo: Companhia das Letras, 2003.

SILVA, Renato Araújo da Silva. Joias africanas e alguns exemplos de suas memórias nas Américas. Disponível em:

$<$ http://www.xiconlab.eventos.dype.com.br/resources/anais/3/1308349962_ARQUIVO_Joia sAfricanaseAlgunsExemplosdesuaMemorianasAmericas.pdf $>$ Acesso em: 20 de maio de 2017.

SILVA, Simone Trindade Vicente da. Referencialidade e representação: um resgate do modo de construção de sentido nas pencas de balangandãs a partir da coleção Museu Carlos Costa Pinto. Dissertação (Mestrado em Belas Artes) - Universidade Federal da Bahia, Bahia, 2005.

_ _ _ _ _. Joias Crioulas. São Paulo: Instituto Victor Brecheret, 2012.

SILVEIRA, Flávio Leonel Abreu da; LIMA FILHO, Manuel Ferreira. Por uma antropologia do objeto documental: entre a "a alma nas coisas" e a coisificação do objeto. Horizontes Antropológicos, Porto Alegre, vol.11, n.23, p. 37-50.

STRICKLAND, Carol.Arte Comentada: da pré-história ao pós-moderno. Rio de Janeiro: Ediouro, 2004.

VERGER, Pierre. Fatumbi: Artigos. São Paulo: Corrupio, 1992.

Recebido em: 31-05-2017

Aceito em: 28-09-2017 